\title{
SOLARUPDATE
}

\section{Newsletter of the}

International Energy

Agency Solar Heating

and Cooling Programme

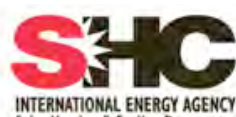

INTERNATIONAL ENERGY AGENCC

Solar Heating \& Cooling Propramme

\section{In This Issue}

I Solar Renovation

I Country Spotlight: Solar Thermal in the United States

\section{Solar Metal Roofing}

5 Solar Cooling in North America

7 Solar Marketplace

8 Programme Inofrmation

\section{Solar Renovation Makes Its Mark}

SHC Task 37, Advanced Housing Renovation with Solar and Conservation, experts have documented over 60 exemplary housing renovation projects. Twelve brochures are posted online with the complete set to be available in mid-20I0, http://iea-shc.org/ publications/task.aspx? Task $=37$.

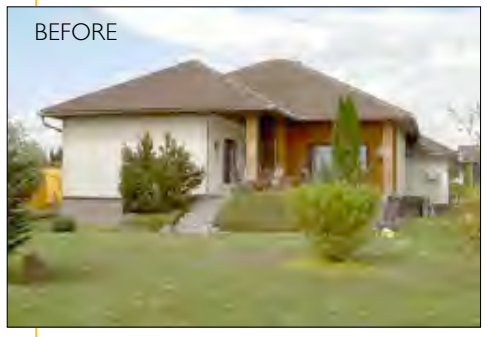

The projects include:

- Apartment buildings

- Penthouses (addition of apartment on existing floor)

- Historic housing

- Row houses

- Single family detached houses

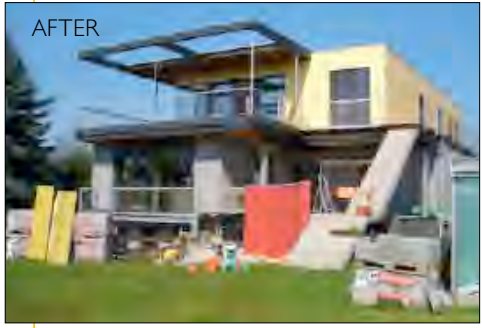

Project results are impressive - the primary energy consumption for space heating and domestic hot water has been reduced by up to $90 \%$. This is all the more impressive because it accounts for primary energy, which reflects the source energy needed to produce the heat. Many of these projects include a solar heating system for domestic hot water and/or space heating.

An example of the renovations documented is a single family bungalow built in the 1980s near Linz, Austria. Prior to the renovation, the house had a space heating addition of a storey, the building has a $30 \mathrm{kWh} / \mathrm{m}^{2}$ space heating demand. To make the home completely energy self-sufficient, the owners plan to change from oil heating to an air/air heat pump and to add a windmill and PV system to generate electricity. The completed renovation has resulted in a reduction in the primary energy for space and water heating from $317 \mathrm{kWh} / \mathrm{m}^{2}$ to $67 \mathrm{kWh} / \mathrm{m}^{2}$.

\section{COUNTRY SPOTLIGHT}

\section{Hot Water and More:} Status and Outlook for Solar Thermal in the United States

The U.S. has a total of 485 MWth of domestic solar water heating (SWH) systems and 7,000 MWth of solar pool heating (SPH) systems. SWH shipments in 2008 increased 50\% over 2007, to 139 MWth, equivalent to roughly 20,500 systems. Solar pool heater shipments declined slightly, by $3 \%$, to $762 \mathrm{MWth}$ in 2008. The challenge in the U.S. is growing the domestic solar water heating market and cultivating space heating and cooling, which are a very small portion of the market. Expanding the geographic range of solar heating and cooling (SHC) technology is also important. In 2008 approximately 37\% of all SWH systems installed were in Hawaii, followed by Florida at 20\%, California at $7 \%$ and even smaller amounts in the other 47 states. With over 80 million detached single-family homes in the U.S., the untapped potential for $\mathrm{SWH}$ as well as space heating and cooling is enormous. 


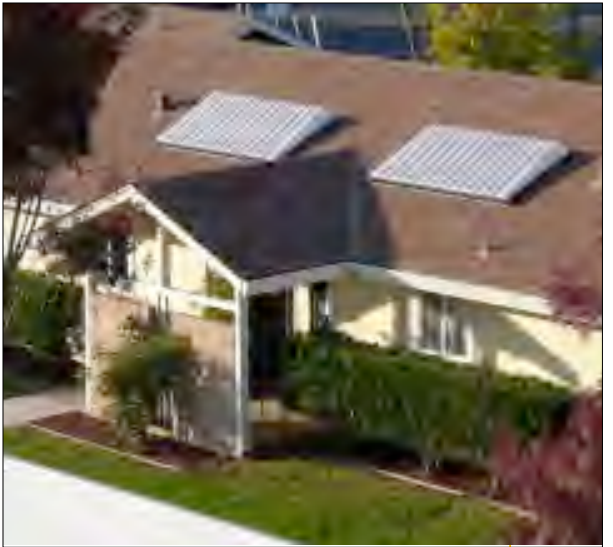

$\Delta$ Figure I. Lakeland Electric, a Florida municipal utility, has SWH installed on customer roofs and then bills them for the energy over the life of the system as part of its utility services.

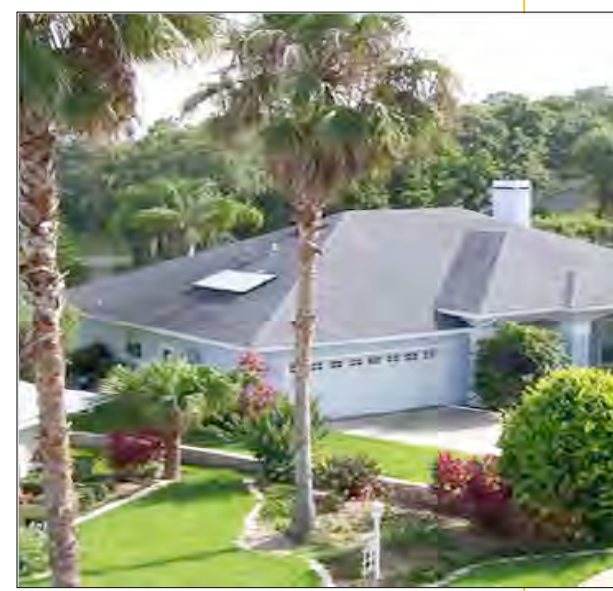

Figure 2. SunCache polymer collector developed by Davis Energy Group and sold by Harpiris Energy. The U.S. Dept. of Energy cost-shared research and development of the systems. These are two out of 65 units installed as part of a rehab project for senior housing implemented by the Sacramento Housing and Redevelopment Agency in California.

\section{Federal Incentives and Research}

A 30\% residential tax credit is available for solar water heating systems. In late 2008 and early 2009 this credit was enhanced by removing a $\$ 2,000$ cap on the credit and extending availability until 2016. A 30\% tax credit for businesses was also extended and credit caps were removed. Significantly, the business credit can be used for solar heating and cooling as well as water heating, and utilities are now eligible.

Removing caps on the business and residential tax credit and long-term extension were top priorities for the solar industry to provide a stable, reliable foundation for expansion.

In technology, the US Department of Energy (DOE) has supported research on low-cost polymer collectors and systems to both reduce the costs of SWH systems and expand their geographic range into the large areas of the country where freeze protection is essential. DOE requested $\$ 7.3$ million in research funding for fiscal year 201 I (up from the $\$ 6.5$ million in fiscal year 2010) to continue research on low-cost systems. The request will also fund research on combined solar heating, cooling, and water heating systems with seasonal storage; and dehumidification applications for combined PV/thermal systems. This work is important to both practical zero-energy buildings and to serving existing buildings which constitute the bulk of building energy consumption in the US.

DOE provides financial support for the Solar Rating and Certification Corporation (SRCC) which has been overseeing standards for collector testing and system ratings in North America since 1980. The Federal residential tax credit and most state or utility incentive programs require equipment that is SRCC certified. DOE also supports the North American Board of Certified Energy Practitioners (NABCEP) to develop training and testing programs for solar thermal system installers.

The IEA Solar Heating and Cooling Programme is an important element of U.S. SHC work, providing excellent leveraging of resources and information sharing in Solar + Heat Pumps (Task 44), Solar Rating and Certification (Task 43), Compact Thermal Energy Storage (Task 42), Net Zero Energy Solar Buildings (Task 40), Polymeric Materials (Task 39), Solar Resource Knowledge Management (Task 36), and Solar Air Conditioning and Refrigeration (Task 38).

\section{State and Local Incentives and Research}

State and utility programs are important factors in U.S. SHC development. States like Hawaii, Arizona and Florida have effectively used financial incentives to build solar thermal markets. Hawaii became the first state to require SWH in new construction, starting in 2010 . In 2010 the industry will also be watching closely California's $\$ 350$ million effort to replace electric and gas water heaters with solar systems, one of the most ambitious new programs in the country. The city of Sacramento supports SWH installations through its municipal utility, and through other city agencies like its Housing and Redevelopment Agency. In Lakeland, Florida the local electric cooperative has SWH systems installed on customer homes, meters and bills for the energy, and sells solar thermal renewable energy certificates to help reduce costs. With more states including solar thermal technologies (I0 so far) in minimum renewable energy requirements for utilities and the availability of the Federal tax credits for utilities, the outlook for more programs is promising. 


\section{Solar Metal Roofing Applies PCM Heat Sink Technology}

\section{task 42}

Since 2000, a research team at Oak Ridge National Laboratory (ORNL) in Oak Ridge, Tennessee, USA has been performing analytical and experimental studies on building envelopes enhanced with different forms of PCM (Phase Change Materials). In 2009, ORNL joined research activities of IEA SHC Task 42 /IEA ECES Annex 24, Compact Thermal Energy Storage - Material Development and System Integration, which is a combined activity of the IEA SHC Programme and the IEA Energy Conservation Through Energy Storage Programme. The main goal of this project is to develop costand energy-effective ways to implement PCM thermal storage in roofs and attics as a means to reduce building thermal loads and shift building peak energy demand time. Proper selection of the PCM heat storage capacity, PCM location, and range of phase transition temperatures are critical for macro-packaged, concentrated PCM. This article presents the research performed during the winter 2009/I0 on a novel configuration of an attic utilizing over-the-deck air ventilated cavities, reflective insulation, and PCM heat sink.

\section{The ORNL Project}

During September - October 2009, research teams representing Metal Construction Association (largest North American trade association representing metal building manufacturers, builders, and material suppliers), CertainTeed (one of the largest U.S. manufactures of thermal insulation and building envelope materials), Unisolar (largest U.S. producer of amorphous silicone PV laminates), Phase Change Energy (manufacture of bio-based PCM), and ORNL installed on the ORNL campus three experimental attics using different roof retrofit strategies. One of the project goals was to evaluate a newly developed sustainable re-roofing technology using amorphous silicone PV laminates integrated with metal roofing panels and PCM heat sink.

PV laminates convert sunlight into electricity and heat simultaneously! In the case of building integrated applications, a relatively high solar absorption of amorphous silicone laminates can be utilized during the winter for solar heating purposes with PCM providing necessary heat storage capacity and increasing overall attic air temperature during the night. However, PV laminates may also generate increased building cooling loads during the cooling season. ${ }^{2}$ That is why in this project the PCM heat sink was designed in a special way to minimize the summer heat gains.

The first test attic represented the traditional roof retrofit where the old roofing materials are totally removed and replaced with a new cover. According to the U.S. National Home Builders Association (NAHB), re-roofing generates an estimated 6.8 million tons of asphalt shingle waste every year, which is equivalent to nearly $3 \%$ of the U.S.'s municipal solid waste. This is why the project team considered two alternative re-roofing methods that did not involve massive removal and disposal of old roofing materials.

For the sake of comparison, in the second attic the metal roofing panels were installed directly

I Van Helden W.G.J., Zondag H.A., 2002. "Photovoltaic Thermal Panels: On The Brick OfDemonstration"- Proceedings Of Pv In Europe - From Pv Technology To Energy Solutions, Conference And Exhibition, October 2002, Rome, Italy 2 Miller W. A. and Kośny J., 2007. "Next-Generation Roofs and Attics for Residential Homes," in Proceedings of the 2007 ACEEE Summer Studies on Energy Efficiency, August 2007. Ko ny J., Yarbrough D.W., Miller W.A. Petrie T.W, Childs P., and Syed A. 2007. "Thermal Performance of PCM-Enhanced Building Envelope Systems," presented at Thermal Envelopes X Conference, December 2007, Clearwater, FL, USA.
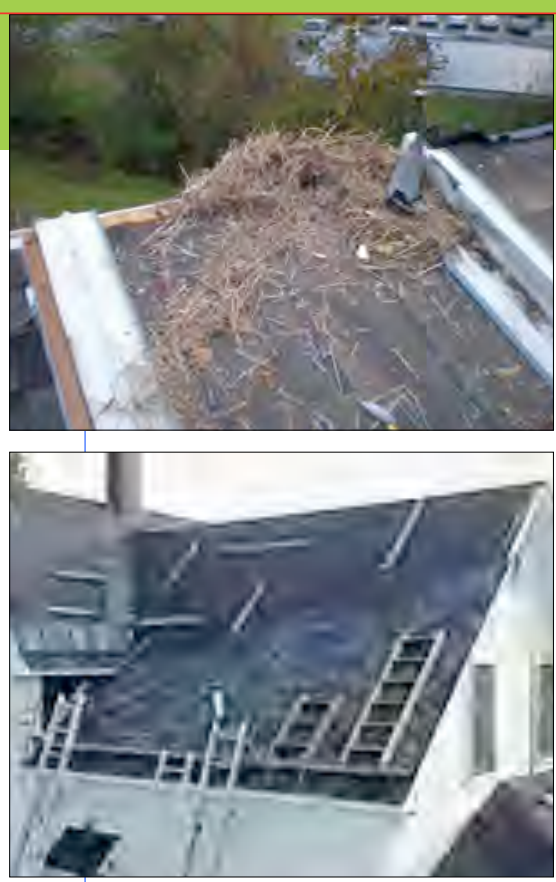

Figure I. Cleaning of the old shingle roof.
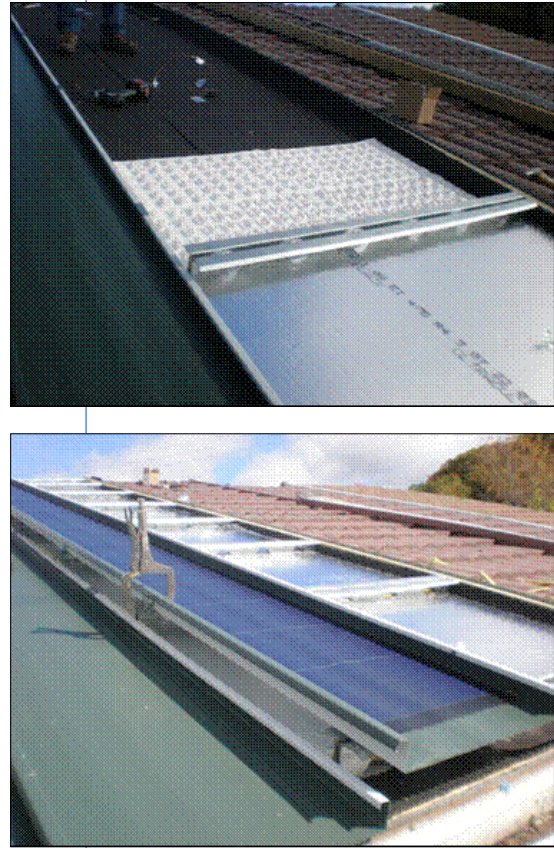

Figure 2. Installation of the PCM heat sink with reflective fiberglass insulation followed with metal roofing panels containing pre-installed PV laminates. 


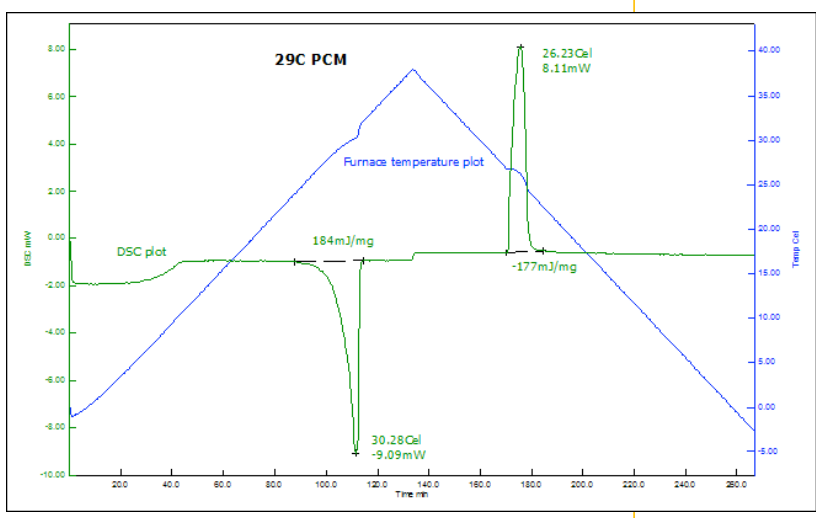

on top of the cleaned existing shingle roof (see Figure I). The new metal roof utilized cool-roof coating technology. The two radiative properties that characterize cool roofs are solar reflectance and thermal emittance. A cool roof minimizes the solar heat gain of a building by first reflecting incoming radiation and then by quickly re-emitting the remaining absorbed portion. As a result, during the summer months the cool roof stays cooler than a traditional roof of similar construction thus reducing the overall building cooling energy loads. This is why on the following thermal performance charts this roof is marked as an infrared-reflective (IRR) roof.

Figure 2 shows the metal roof panels in the third attic had pre-installed amorphous silicone PV laminates. These metal panels were installed directly

$\triangle$ Figure 3. DSC test data for PCM used in attic experiments. The experimental data was recorded during a heating-cooling experiment. The left axis represents recorded DSC voltage and the right axis shows temperatures in degree $\mathbf{C}$. on top of the old roof. In order to minimize thermal stress generated during sunny days by the PV laminate, an internal heat sink combined with air ventilation channels were used. A bio-based phase change material (PCM) with a melting point of $29^{\circ} \mathrm{C}$ and total enthalpy between 180 and $190 \mathrm{~J} / \mathrm{g}$ was used for this roof assembly. ${ }^{3}$ On this roof, the PCM was macro-packaged in between two layers of heavy-duty plastic foil forming arrays of PCM cells. Figure 3 shows results of the differential scanning calorimeter (DSC) tests for this material.

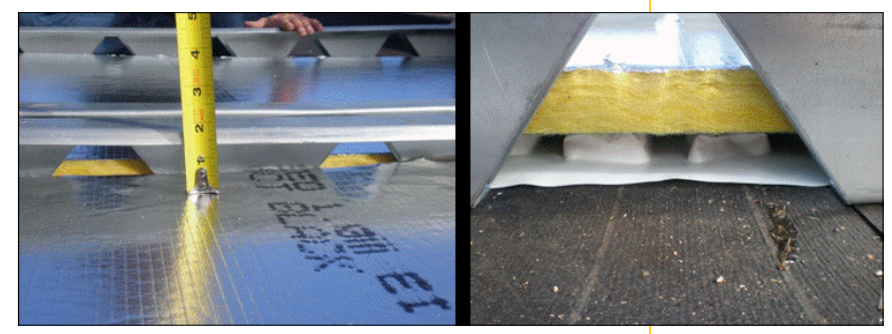

Figure 4 shows the construction of the panel, at the top the PCM is covered by about a $2 \mathrm{~cm}$ thick layer of high-density fiberglass insulation with a reflective surface and the two air cavities between the PCM cells and above the fiberglass insulation help the over-the-deck natural air ventilation. It is anticipated that during the summer months this extra ventilation capability will help reduce the attic generated cooling loads.

During the 2009/10 winter months, all three attics were field tested at

Figure 4. Location of the PCM heat sink directly on top of the old roofing material with air channels above and below the fiberglass insulation.
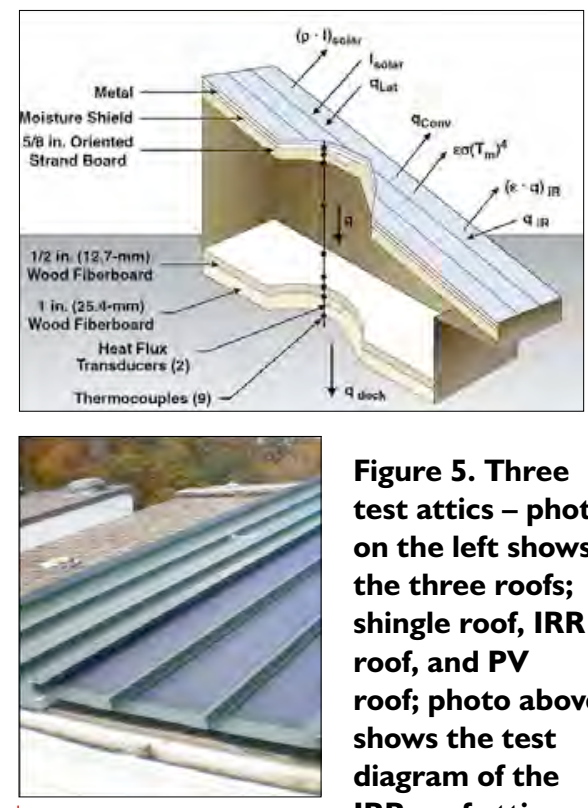

Figure 5. Three test attics - photo on the left shows the three roofs; shingle roof, IRR roof, and PV roof; photo above shows the test diagram of the IRR roof attic. the ORNL Field Exposure Testing Facility and their thermal performances were compared. Since earlier studies demonstrated that in the southern U.S, roof surface temperatures can easily exceed $30^{\circ} \mathrm{C}$ during the winter months, it was expected that the PCM heat sink might be at least partially useful during the heating season. ${ }^{4}$

\section{Field Test Results}

Thermal performances of these three test attics were monitored over four months in the winter 2009/2010 and experimental data for each of the test assemblies were compared. As shown in Figure 5, detailed temperature profiles were recorded and heat flux measurements taken for each test attic. From the roof energy performance standpoint, internal attic air temperature and attic floor heat flow are the most important performance control factors. The higher the average attic air temperature during the winter the lower the attic heat losses.

Initially, it was expected that the majority of the winter energy performance improvement in the solar roof using PCM heat sink would come from the increased R-value of the top of the roof (due to combined thermal resistance of the fiberglass with reflective surface, PCM, and two air cavities). PCM was designed to work mostly during the summer and midseason months. However, the temperature measurements demonstrated that PCM with a $29^{\circ} \mathrm{C}$ melting point, installed just under the roof surface, could easily go through the phase transitions during sunny winter days (see Figure 6).

3 Kośny J., Stovall T., Yarbrough D.W. - 2009 "Dynamic Heat Flow Measurements to Study the Distribution of Phase-Change Material in an Insulation Matrix - Proceedings of the 2009 International Thermal Conductivity Conference (ITCC) and the International Thermal Expansion Symposium (ITES) - August 29 - September 2, 2009 Pittsburgh, PA USA.

4 Miller W. A. and Kośny J., 2007. "Next-Generation Roofs and Attics for Residential Homes," in Proceedings of the 2007 ACEEE Summer Studies on Energy Efficiency, August 2007. 
Figure 7 shows the daily fluctuation of the attic floor heat fluxes recorded during two sunny days during November 2009 and January 2010. Significant solar gains can be observed in the conventional shingle and IRR attics. However during the night, these two attics show about $50 \%$ to $80 \%$ higher heat losses compared to the PV attic with the PCM-heat sink. It is a combined effect of extra insulation and PCM latent heat released during the night. About a 3-hour lag time in the PV attic is additional evidence that PCM really worked during these days.

Figure 8 confirms the above findings. It depicts recorded average weekly attic air temperatures. In both test attics where new metal roofs were installed directly on top of the existing structures, the old materials were utilized as a free (since already existing) enhancement of moisture and thermal protection. In addition, the PV attic with the PCM heat sink, 2-cm thick layer of fiberglass insulation, reflective surface, and two air cavities were utilized as extra thermal insulation. As a result, average winter attic air temperatures of the IRR and PV attics were about $2.5^{\circ} \mathrm{C}$ and $5^{\circ} \mathrm{C}$ higher from the shingle attic air, respectively.

Figure 9 shows the recorded average weekly attic heat losses. It can be observed that the average IRR attic and PV attic heat losses are about 18\% and 30\% lower, respectively, compared to the conventional shingle attic.

In summary, the test results show that re-roofing using a metal roof and PV technology with the PCM heat sink can be a very effective way of repairing existing roofs without generating solid waste. This new sustainable way of re-roofing not only improves overall performance of existing roofs, but also generates inexpensive solar electricity. The ORNL attic tests will be continued this summer to fully investigate the PCM energy performance.

This article was contributed by Jan Kośny, kosnyi@ornl.gov (Task 42 expert), William Miller, Phillip Childs, and Kaushik Biswas of Oak Ridge National Laboratory (ORNL), Oak Ridge, TN, USA. The authors would like to acknowledge the U.S. Department of Energy funding for the ORNL's phase change material research program, in particular to Mr. Marc LaFrance. The above project was also performed thanks to the direct funding and in-kind contributions from the members of the Metal Construction Association.

For more information on SHC Task 42 visit, www.iea-shc.org/task42/index.html or contact the SHC Task Operating Agent, Wim van Helden, wim@wimvanhelden.com.

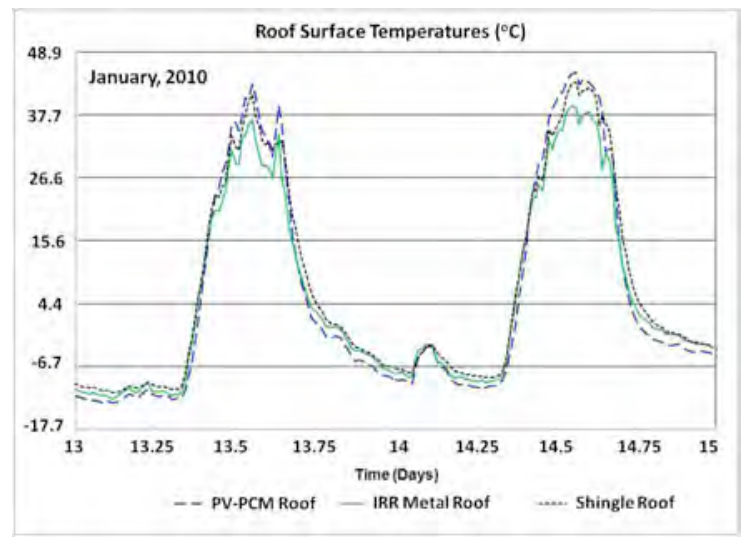

Figure 6.

Roof surface temperatures recorded during two sunny days in January 2010.

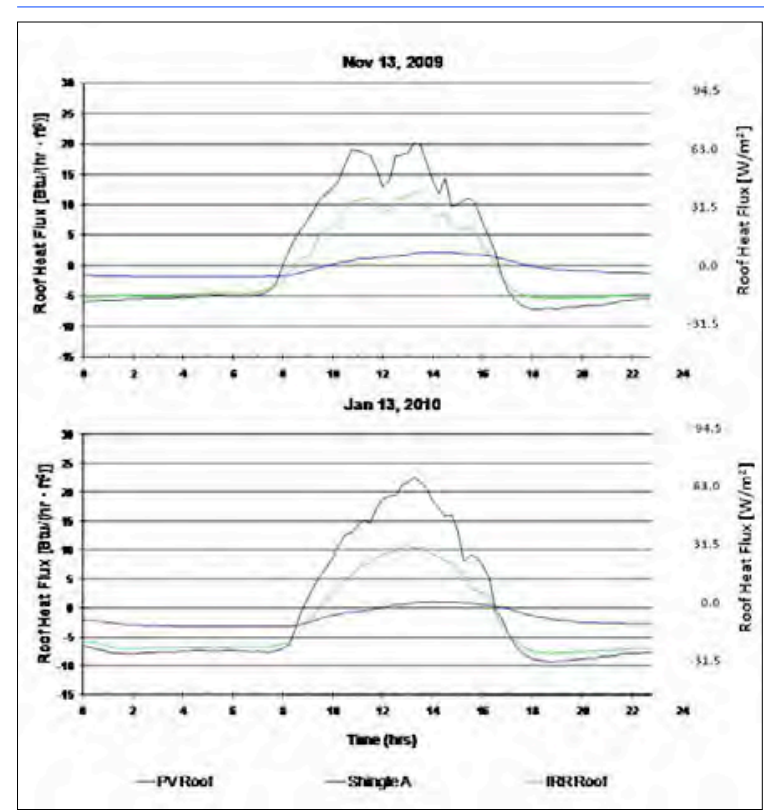

4 Figure 7.

Attic floor heat flux profiles recorded during two sunny days in late fall and winter.

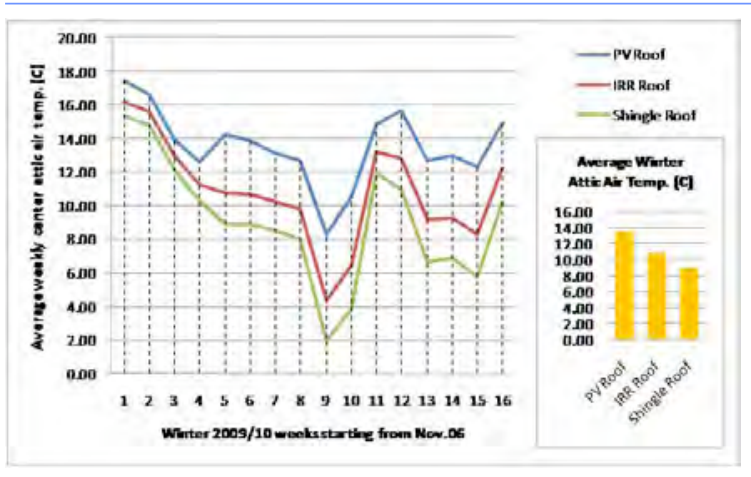

$\triangleleft$ Figure 8.

Average weekly attic air temperatures recorded during the winter season 2009/10.

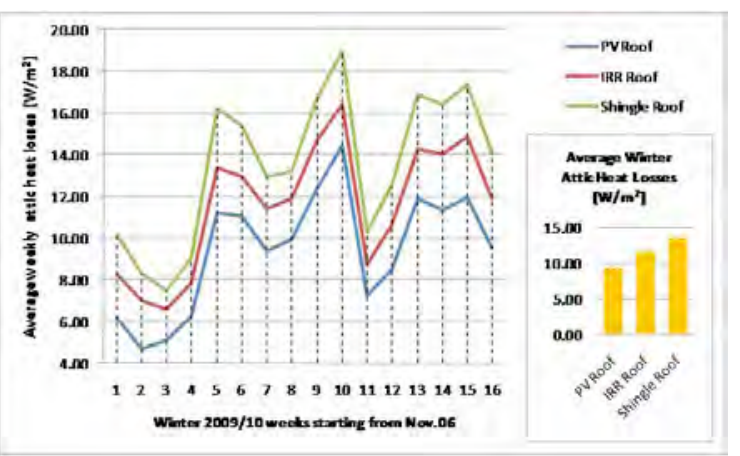

$\triangleleft$ Figure 9.

Average weekly attic floor heat losses recorded during the winter season 2009/10. 


\section{Warming to Solar Cooling in North America}

From the first quarter of the last century to today, air-conditioning (AC) has evolved from a niche application to almost a necessity in many parts of United States and Canada. In fact, in a poll conducted in 2004 by the Henry Ford Museum, 2.5 million Americans voted air-conditioning the best American invention in the past 75 years, beating even the personal computer. Some even argue that the demographic shift towards the South seen in the last decades would not have been possible without such technology.

In 2005, 8 I million housing units in the United States had air-conditioning, 82\% of the total, and in 20033.6 million commercial buildings used the technology, which represented $88 \%$ of the total commercial floor space in the country. Even in Canada, which has a much cooler climate, $38 \%$ of the housing units have air-conditioning, mostly in Ontario, where $65 \%$ of the houses enjoy AC in the summer. Such widespread use of air-conditioning is associated with significant energy and emission impacts, besides high peak loads on utility grids during the summer months. Therefore, it seems logical to use solar energy to provide air-conditioning in North America.

To explore such a possibility and to help spread information regarding solar thermal air-conditioning, SHC Task 38, Solar Air-Conditioning and Refrigeration, promoted a public workshop during the AHR Expo in Orlando, Florida, on the 27th of January. According to trade show organizers, the AHR Expo is the largest HVAC show in the world with more than 34,000 attendees in 2010. The workshop, supported by Natural Resources Canada, brought together solar thermal, HVAC, and building professionals. The sold out event had over 100 participants, and European and North American experts presented the state-of-the-art of solar thermal air-conditioning.

As part of the SHC Task activities, a survey of solar cooling systems in the United States and Canada was conducted and presented during the workshop. The good news is that even without any specific programs or support, 22 installations were identified, 15 of those less than 5 years old. However, the numbers show a strong lag between European and North American market development. Data presented by Dr. Wolfram Sparber from EURAC Research in Italy showed that in

SHC News

To learn what's happening

and what's been published

just click on

http://iea-shc.org/ whatsnew.aspx

A new addition is Task

Highlights under Recent

Publications. These Highlights

share news on recent

Task results. 2009 more than 150 systems were identified in Spain and Germany alone.

Despite the significant market potential in North America, evident from the market numbers for AC, solar thermal air-conditioning faces many challenges in the region, such as relatively low electricity prices, lack of knowledge by solar and building professionals regarding the technology, and absence of specific programs to support new installations with the required monitoring and evaluation. Many workshop participants identified such programs as critical for the development of the technology in North America. Two other initiatives identified as important by participants were to hold similar events in other parts of North America and to organize a regional interest group that would support policy decisions and help gather and disseminate information on solar thermal air-conditioning in the United States and Canada.

The final conclusion of the event was that there is enormous potential for solar cooling in North America, but without organized and co-ordinated action and support it is unlikely such potential will ever be realized. And that shows the importance of such events - they bring together many participants capable of starting this much needed development process.

This article was contributed by Lúcio Mesquita, Thermosol Consulting, Canada, and SHC Task 38 expert, mesquita@thermosolconsulting.com. Mr. Mesquita and Prof. Steve Harrison of Queen's University,

Canada organized the AHR Expo workshop. Most of the workshop presentations can be found at http://www.iea-shc.org/task38/events/2010-01-27/index.html. For more information on SHC Task 38, Solar Air-Conditioning and Refrigeration, visit http:/liea-shc.org/task38/index.html. The author acknowledges the support from Natural Resources Canada and all workshop speakers. 


\section{MarketPlace}

\section{storage and cooling}

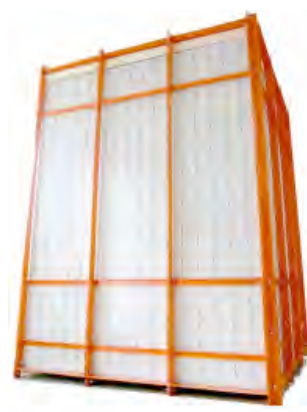

Source: FSAVE.de

The Solar Heating and Cooling Programme is not only making strides in R\&D, but also impacting the building sector. This section of the newsletter highlights solar technologies that have been developed or conceptualized in a SHC Task and are now being commercially manufactured, marketed or used.

\section{Heat Storage}

Within a German research project supported by BMU, the SHC Task 39, Polymeric Materials for Solar Thermal Applications, partners at Kassel University developed a novel buffer store of PP-H, which should overcome the market barrier of present storage technologies for medium-sized solar thermal systems $\left(>20 \mathrm{~m}^{2}\right)$. Due to low production costs, flexible and easy installation of the present storage design mediumsized solar thermal systems should become more competitive. Since 2009, this concept has been marketed by the company FSAVE Solartechnik GmbH.

\section{Solar Cooling at Tunisian Winery}

A solar cooling system application installed at a winery in Tunisia by the Politecnico di Milano within the European project MEDISCO (MEDiterranean food and agro Industry applications of Solar COoling technologies) was awarded with the Energy Globe Award Tunisia 2009. This installation is part of the monitoring activities within the framework of SHC Task 38, Solar Air-Conditioning and Refrigeration, and several Task 38 participants are contributing to this project.
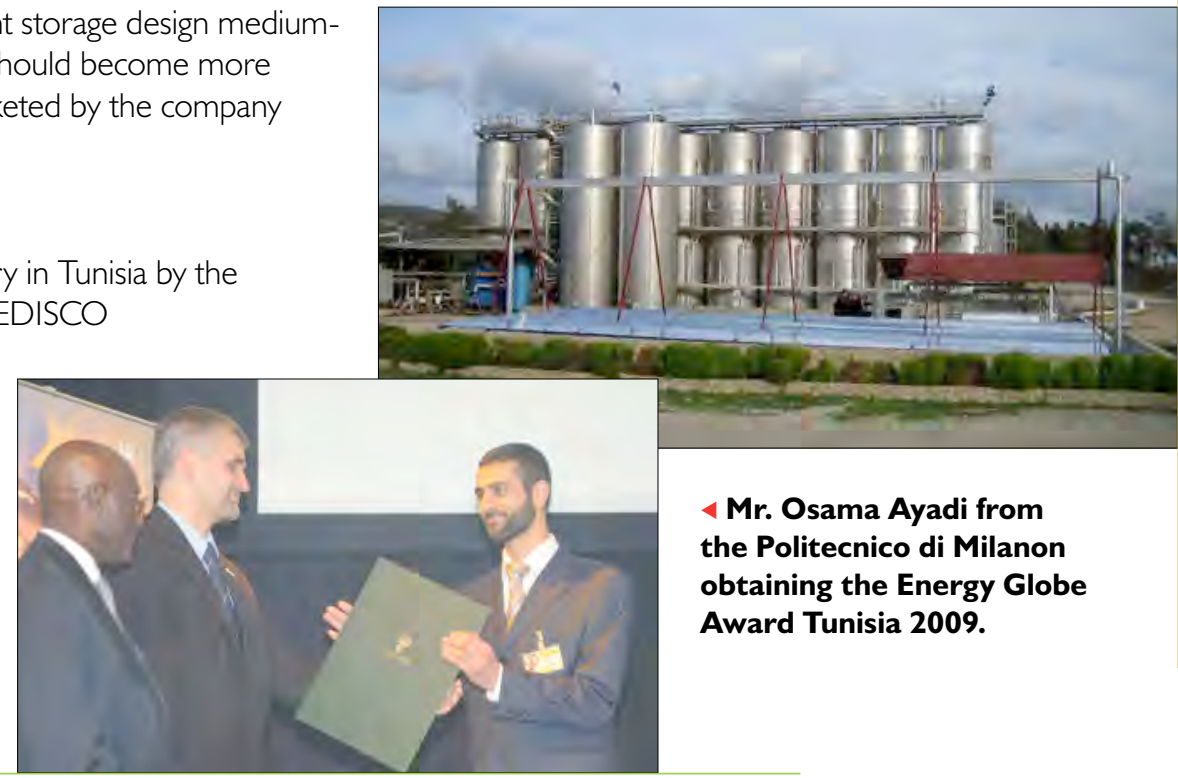

$\triangleleft$ Mr. Osama Ayadi from the Politecnico di Milanon obtaining the Energy Globe Award Tunisia 2009.

Solar Thermal in the U.S. continued from page 2

\section{U.S. Outlook}

A typical 64 square foot (approximately $6 \mathrm{~m}^{2}$ ) SWH system produces approximately the same amount of energy as a I kW PV system over the course of a year. Utilities, regulators and advocates of renewable energy are starting to understand that comparison and factor the affordability and value of SHC technology into their renewable energy plans. Building energy use accounts for $38 \%$ of US carbon dioxide emissions and nearly $8 \%$ of global emissions. The primary energy used in the US for water heating, space heating, and space cooling comes to nearly $42 \%$ of all energy use in buildings. Clearly $\mathrm{SHC}$ technologies could have a major role in making U.S. energy use more sustainable.

Over the next five years with a combination of research and development, stable Federal incentives, and innovative state and local action the U.S. is poised to get beyond its current limits. Beyond solar hot water and pool heating to solar space conditioning including cooling, beyond Hawail and the Sun Belt to new markets and regions, beyond policies and incentives that undervalue solar thermal energy and on to policies and incentives that recognize solar heating and coolings full performance, environmental and economic value.

This article was contributed by Kevin DeGroat, Antares Group, kdegroat@antares.org; Robert Hassett, US Delegate to the IEA SHC Executive Committee, Robert.Hassett@ee.doe.gov; and Les Nelson, Co-Operating Agent for IEA SHC Task 43, Solar Rating and Certification Procedure, Inelson@westernrenewables.com 

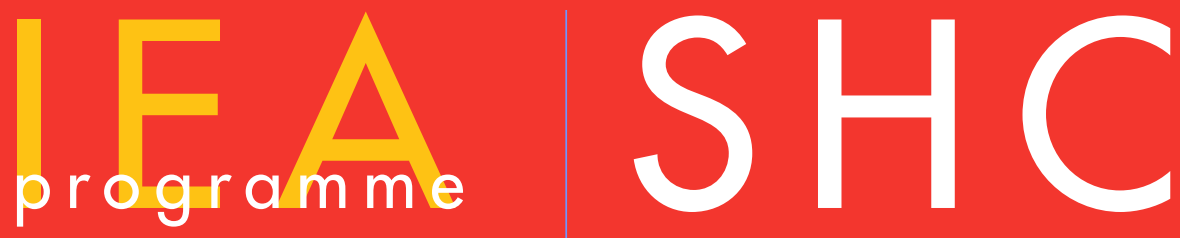

The International Energy Agency was

formed in 1974 within the framework of the Organization for Economic Cooperation and Development (OECD) to implement a program of international energy cooperation among its member countries, including collaborative research, development and demonstration projects in new energy technologies. The members of the IEA Solar Heating and Cooling Agreement have initiated a total of 44 R\&D projects (known as Tasks) to advance solar technologies for buildings. The overall Programme is managed by an Executive Committee while the individual Tasks are led by Operating Agents.

\section{Current Tasks and Operating Agents}

Solar Resource Knowledge Management

Dr. David Renné

National Renewable Energy Lab

1617 Cole Blvd.

Golden, CO 8040I

UNITED STATES

david_renne@nrel.gov

Advanced Housing Renovation with Solar \& Conservation

Mr. Fritjof Salvesen

KanEnergi AS

Hoffsveien 13

0275 Oslo

NORWAY

fs@kanenergi.no

Solar Air-Conditioning and Refrigeration

Dr. Hans-Martin Henning Fraunhofer Institute for Solar

Energy Systems

Heidenhofstr. 2

D-79 |I 0 Frieburg

GERMANY

hans-martin.henning@ise.

fraunhofer.de
Polymeric Materials for Solar Thermal Applications

Mr. Michael Köhl

Fraunhofer Institute for Solar

Energy Sytems

Heidenhofstr. 2

D-79 || 0 Freiburg

GERMANY

michael.koehl@ise.fraunhofer.de

Net Zero Energy Solar

Buildings

Mr. Josef Ayoub

CanmetENERGY

Natural Resources Canada

1615, boul. Lionel-Boulet

Varennes, Quebec J3X IS6

CANADA

Josef.Ayoub@rncan-nrcan.gc.ca

Compact Thermal Energy

Storage

Mr. Wim van Helden

ECN Energy Research Centre of the Netherlands

P.O. Box I

NL 1755 ZG Petten

NETHERLANDS

vanhelden@ecn.n
Solar Energy and Architecture Ms. Maria Wall

Lund University

P.O. Box 118

SE-22I 00 Lund

SWEDEN

maria.wall@ebd.Ith.se

Solar Rating and Certification

Procedures

Mr. Les Nelson

Western Renewables Group UNITED STATES

Inelson@westernrenewables.com

Mr. Jen Erik Neilson

Plan Energi

DENMARK

jen@solarkey.dk

Solar and Heat Pumps Mr. Jean-Christophe Hadorn BASE Consultants

8 rue du Nant - CP 6268

$\mathrm{CH}$ - 1211 Genève 6

SWITZERLAND

jchadorn@baseconsultants.com

\section{$S \bigcirc L A R U P D A T E$}

The Newsletter of the IEA Solar Heating and Cooling Programme

No. 52, May 2010

Prepared for the IEA Solar Heating and Cooling Executive Committee

by

KMGroup, USA

Editor:

Pamela Murphy

This newsletter is intended to provide information to its readers on the activities of the IEA Solar Heating and Cooling Programme. Its contents do not necessarily reflect the viewpoints or policies of the International Energy Agency or its member countries, the IEA Solar Heating and Cooling

Programme member countries or the participating researchers

\section{wwwiea-shc.org}

Member Countries and Executive Committee Members.

$\begin{array}{ll}\text { AUSTRALIA } & \text { Mr. M. Maffucci } \\ \text { AUSTRIA } & \text { Mr. W. Weiss } \\ \text { BELGIUM } & \text { Prof. A. De Herde } \\ \text { CANADA } & \text { Mr. D. McClenahan } \\ \text { DENMARK } & \text { Mr. J. Windeleff } \\ \text { EUROPEAN } & \\ \text { COMMISSION } & \text { Mr. J. Riesgo } \\ \text { FINLAND } & \\ \text { FRANCE } & \text { Mr. C. Coulaud } \\ \text { GERMANY } & \text { Mr. M. Kratz } \\ \text { ITALY } & \text { Mr. M. Zinzi } \\ \text { MEXICO } & \text { Dr. W. R. Gomez-Franco } \\ \text { NETHERLANDS } & \text { Mr. L. Bosselaar } \\ \text { NEW ZEALAND } & \text { Mr. M. Donn } \\ \text { NORWAY } & \text { Dr. A. Lien } \\ \text { PORTUGAL } & \text { Mr. J. F. Mendes } \\ \text { SPAIN } & \text { Dr. E. Rojas } \\ \text { SWEDEN } & \text { Mr. M. Törnell } \\ \text { SWITZERLAND } & \text { Mr. A. Eckmanns } \\ \text { UNITED STATES } & \text { Mr. R. Hassett }\end{array}$

CHAIRMAN

Mr. Doug McClenahan

CanmetENERGY

Natural Resources Canada

580 Booth Street

Ottawa, Ontario KIA OE4

CANADA

Tel: + I/613/996 6078

e-mail:dmcclena@nrcan.gc.ca

\section{SHC SECRETARIATI}

Ms. Pamela Murphy

KMGroup

913। S. Lake Shore Dr.

Cedar, MI 4962

USA

Tel: + I/23I/620-0634

e-mail: secretariat@iea-shc.org 